\title{
OLD FOSSILS OR SILVER SURFERS: PHRASEOLOGICAL CONCEPTUALIZATION OF OLD AGE IN ENGLISH
}

\section{Holyk S. V.}

\section{INTRODUCTION}

The development of phraseology as a branch of linguistics is characterized by different stages, namely classical, postclassical and modern, each of them with their own priorities, such as structural (or formal), functional-semantic or anthropocentric respectively. Contemporary linguistics is marked with the dominance of the anthropocentric approach which lays emphasis on the study of phraseological units as verbal means used to conceptualize the language world view, e.g. Benczes (2002), Selivanova (2004), etc.

According to Selivanova, modern phraseology as a discipline aims, among other goals, at the study of the interaction between phraseological units, on the one hand, and the conceptual structures, the mechanisms of cognition, stereotypical views on the people and their inner reflective experience expressed by these units, on the other hand ${ }^{1}$.

This predetermines the topicality of this paper which aims to investigate the conceptualization of OLD AGE by means of English phraseological units selected from contemporary lexicographical sources.

Phraseological units can serve as an important source of information about the people, their culture and mentality. Being concise in their form, they include knowledge about the world order and person's inner world, encoding the system of ethical and moral norms. Moreover, they constitute an important part of the philosophy of life, regulating the norms of behavior in society ${ }^{2}$.

In linguistics, it has been stated that there seems to be a correlation between phraseological units and native speakers' background knowledge, their historical and cultural traditions. Maslova believes that phraseological units describe those features which are commonly associated with certain world view and reflect speakers' attitude to objects and phenomena, as well as evaluate them ${ }^{3}$. A large number of cognitive

\footnotetext{
${ }^{1}$ Селіванова О. Нариси з української фразеології (психокогнітивний та етнокультурний аспекти): монографія. К. Черкаси: Брама, 2004. С. 8.

2 Алефиренко Н.Ф. Фразеология в свете современных лингвистических парадигм. М.: ООО Изд-во «Элипс», 2008. С. 23-25.

${ }^{3}$ Маслова В.А. Лингвокультурология: учеб. пособие для студ. высш. учеб. зав. М. : Издательский центр «Академия», 2001. С. 93.
} 
scientists also demonstrate the link or interaction between perception and action. For example, Gibbs assumes that when we look at the objects, which is a goal-oriented task, we perceive it. Accordingly, "the world is conceptualized in part as patterns of possible bodily interactions, or affordances (e.g., how we can move our hands and fingers, our legs and bodies, our eyes and ears, to deal with the world that presents itself)" ${ }^{4}$.

Undoubtedly, phraseological units are ethnically marked and appeal to native speakers' beliefs concerning the phenomena of national culture, both spiritual and material. The inner form of the phraseological unit is said to encode verbal associations in its semantic structure ${ }^{5}$. Thus, phraseological units can be approached as "microtexts" that express both explicit and implicit types of modality, characteristic of propositional lingual signs ${ }^{6}$.

Researchers lay emphasis on the special nominative function of phraseological units, that makes them different from words or phrases ${ }^{7}$. In cognitive linguistics, however, the analysis proceeds not from the interaction between the material form and semantic content of the sign, but from the correlation between explicit information, expressed by the material form, and implicit information, left unexpressed by the lingual sign. Thus, cognitive linguists pursue the aim to define the correlation between two semantic planes or cognitive levels - the inner form and the meaning - the way of expressing the knowledge encoded in a sign ${ }^{8}$.

The concept is said to be the key term of cognitive linguistics and is commonly defined as the main unit of structured knowledge representation in the human mind. ${ }^{9}$ Since it is loaded with cultural information, the conceptual analysis contributes to the description of the national world view. Concepts can be verbalized by different nominative units (e.g., words, word combinations, idioms etc.). However, only the latter are based on everyday ritual experience of different ethnocultural communities, their traditions, habits and beliefs.

\footnotetext{
${ }^{4}$ Gibbs R. W., de Macedo A. Cristina P. S. Metaphor and Embodied Cognition (Metáfora e cognição corpórea). D.E.L.T.A., 26:especial, 2010. P. 681.

${ }^{5}$ Телия В.Н. Русская фразеология: Семантический, прагматический и лингвокультурный аспекты. М.:«Языки русской культуры», 1996. С. 215.

${ }^{6}$ Телия В.Н. Фактор культуры и воспроизводимость фразеологизмов - знаков - микротекстов. // Сокровенные смыслы. Слово. Текст. Культура. М., 2004. С. 677.

${ }^{7}$ Телия В.Н. Русская фразеология: Семантический, прагматический и лингвокультурный аспекты. М.:«Языки русской культуры», 1996. С. 80.

${ }^{8}$ Иванова Е.В. Мир в английских и русских пословицах. СПб.: Изд-во С.-Петерб. ун-та, 2006. С. 63.

${ }^{9}$ Селіванова О. Сучасна лінгвістика: термінологічна енциклопедія. Полтава: Довкілля-К, 2006. C. 292-293.
} 
The present study attempts to analyze the complex of judgements about OLD AGE in English as they are encoded in phraseological units. It must be emphasized that this research does not account for all the OLD AGE idioms. Conversely, it aims to define the most common tendencies within this segment of the nominative field of the concept.

\section{Phraseological units: the challenges of their semantic content analysis}

Although phraseological units have been the object of heated discussions for many reasons, the main one is their specific semantic character. The rise of modern attitudes to phraseological units is greatly influenced by the structural and functional-semantic approaches when the notion of phraseological meaning was first introduced and the subfoundations of their motivation were put forward (e.g., Vinogradov, Kunin etc.). This classical period is characterized by the so called "noncompositional view" on the phraseological units, when their overall meaning is said to be unmotivated by the meanings of their constituents ${ }^{10}$.

It has become traditional to state that the phraseological system differs from other language subsystems in its anthropological orientation (anthropocentrism) which is mostly expressed by its selective nominative function. Linguists believe that phraseological units verbalize those elements of the world that prove to be the most relevant for a particular lingual community. Drawing on Selivanova's ideas, this study views phraseological units as fixed and bound, regularly recreated in speech word combinations, that are based on ethnic stereotypes, represent the culture of the people and are characterized by figurative and expressive meanings ${ }^{11}$.

The terms "idiom", "phraseologism" and "phraseological unit" are used in this paper synonymically to designate semantically bound word combinations regularly recreated in speech as fixed units. In many researches of the classical period, these units are defined as polylexemic expressions whose meanings cannot be deduced from the meaning of its parts ${ }^{12}$.

One of the most controversial issues related to the study of phraseological units is the nature of their meaning. At present, there is hardly much agreement among researchers as to the semantic character

\footnotetext{
${ }^{10}$ Benczes R. The semantics of idioms: a cognitive linguistic approach. // The Even Yearbook, 5, 2002. Р. 18.

${ }^{11}$ Селіванова О. Сучасна лінгвістика: термінологічна енциклопедія. Полтава: Довкілля-К, 2006. C. 641 .

${ }^{12}$ Benczes R. The semantics of idioms: a cognitive linguistic approach. // The Even Yearbook, 5, 2002. P. 18.
} 
of these lingual units. Some of them believe that phraseological units tend to possess the lexical meaning, although rather specific, that cannot be viewed as the total of its constituent parts. Moreover, idioms are said to be syntactically frozen elements ${ }^{13}$. However, it is in the recent years that another view has appeared, which "maintains that the "connection" between the constituents' literal meaning and the overall figurative meaning arises from "motivation" stemming from the unconscious conceptual structures in the language user's head"14.

The mechanisms of phraseological units formation have always aroused a lot of interest among linguists, e.g. Kövecses \& Szabó (1996), Teliia (1996) etc. They mostly agree that this process is complex and differs from that of lexical meaning formation. It is Teliia who first introduces the notion of "idiomatic formation" as a special type of nomination commonly performed as metaphorization ${ }^{15}$.Accordingly, metaphor proves to be the most significant element for idiomaticity. In cognitive linguistics, according to Benczes, idioms are said to be motivated, and their motivation arises from conceptual metaphor, conceptual metonymy and conventional images, which provide "link" between the idiom and its meaning ${ }^{16}$. In this respect, it seems quite perspective to apply Lakoff's approach to analyze standard ways of establishing interaction between the conceptualized domains. As outlined in Metaphors We Live By (Lakoff \& Johnson 1980), a metaphor is a cognitive process that allows one domain of experience, the target domain, to be reasoned about in terms of another, the source domain. The metaphor allows us to export conceptual structure about the more concrete domain to the more abstract target domain that is referred to as metaphorization ${ }^{17}$. This means that some parts of the target domain are structured similarly to the source domain (metaphorical mapping).

In Gibbs' The Poetics of Mind, an attempt is made to challenge the widespread view when idioms and proverbs are said to be dead metaphors. The author suggests, instead, that they retain much of their metaphoricity ${ }^{18}$. In more recent works, the researcher views metaphors not only as a kind of poetic language, but mostly as a scheme of thought. In his words, "Metaphor, far from being an ornamental aspect of

\footnotetext{
${ }^{13}$ Gibbs R. W. The Poetics of Mind. Cambridge: Cambridge University Press, 1994. P. 271.

${ }^{14}$ Benczes R. The semantics of idioms: a cognitive linguistic approach. // The Even Yearbook, 5, 2002. P. 17.

${ }_{15}$ Телия В.Н. Русская фразеология: Семантический, прагматический и лингвокультурный аспекты. М.: «Языки русской культуры», 1996. С. 133-154.

${ }^{16}$ Benczes R. The semantics of idioms: a cognitive linguistic approach. // The Even Yearbook, 5, 2002. P. 28.

${ }^{17}$ Lakoff G., Johnson M. Metaphors we Live by. Chicago: University of Chicago Press, 1980. P. 3.

${ }^{18}$ Gibbs R. W. The Poetics of Mind. Cambridge: Cambridge University Press, 1994.
} 
language, is integral to the way people speak and think about a wide variety of human events and abstract concepts”"19.

The structure of the meaning encoded in the phraseological unit as an indirect nomination is usually based on the associative image between the formal presentation and the referent of nomination which is not directly (explicitly) expressed in the lingual sign, although it is vital for its existence.

\section{Thematic groups of OLD AGE phraseological units}

This study proceeds from the idea about the structure of the concept's nominative field as a three-component entity, commonly divided into the nucleus, the medial zone and periphery. The constituents of the concept, i.e., conceptual features as separate properties of phenomena, which are differently perceived and reflected in the human mind, make up its nuclear-medial zone (basic notions) and periphery (knowledge brought about by culture, traditions and experience). Phraseological units are responsible for the content of the interpretational field of the concept, constituted by judgement, evaluation and stereotypes. It is quite obvious that historically, with the changes in the life of society, these peripheral features are also liable to modifications.

The difference between the periphery and nuclear/medial zone of the concept's nominative field consists in the fact that the constituents of the periphery are commonly metaphoricalized. The periphery is composed when the concept is viewed against the cultural background of the English-speaking community. Thus, the knowledge about OLD AGE derives from the personal experience of native speakers influenced by their peculiar world views and values.

Characterizing the idiomatic components of the concept's nominative field, their variety and topical diversity should be mentioned. All the units are subdivided into thematic groups which are used to designate different components of the conceptual content (i.e. conceptual features).

In this work, phraseological material has been selected on the basis of their semantic components. Preliminary results of the semantic analysis might indicate that dominant conceptualizations of OLD AGE and ageing in English, as indexed in different dictionary definitions, include:

- physical and physiological characteristics;

- temporal features which describe the period, years or time of life;

- existential features;

${ }^{19}$ Gibbs R. W., de Macedo A. Cristina P. S. Metaphor and Embodied Cognition (Metáfora e cognição corpórea). D.E.L.T.A., 26:especial, 2010 P. 680. 
- categorizational ontological features which describe the state of the person.

The units selected from lexicographical sources represent social, physical and moral properties of OLD AGE as perceived by native speakers and prove to be clearly anthropocentric, and this feature of anthropocentrism is observed in different thematic groups.

1. The first group of phraseological units is used to represent the conceptual feature of decline. Accordingly, OLD AGE causes incapability, physical changes in the body, decline of vigor and loss of vitality.

Long in the tooth - old or getting old;

To feel one's age - to have less energy.

Old age leads to physical incapability, it is viewed as the time of diseases, the state with bodily changes (hair greying, loosing teeth, wrinkled face and body etc.). The phraseological unit long in the tooth was first used with the reference to horses, since as they get older, their gums recede and their teeth appear longer. Accordingly, a mouthful of long teeth is assumed to be a sign of getting old. Today, this phrase is used to describe the age of people who are old or getting old providing the physical characterization of old age.

The older people are usually feeble, not interested in the activities around them.

The idiom To feel one's age means [to have less energy] and encodes the decline of mental and physical capability. According to Merriam Webster's Dictionary, it means [to feel the effects of growing older]. This definition seems to illustrate the widespread medicalized approach to old age which associates getting older with less physical activity and loss of vitality and vigour.

2. In the second group, OLD AGE is represented by out-dated, oldfashioned, conservative elderly people with little prospect for the future.

This feature can be exemplified by the following units:

Like a Rip van Winkle - out of touch with modern life.

Yesterday's man - must make way for younger generation.

That's old hat - old fashioned, out-of-date.

Old fossil - an elderly old-fashioned person.

The blue-rinse brigade - elderly women with traditional, conservative views.

For instance, the first unit presents the metaphorical mapping from the source domain (Rip van Winkle) into the target domain (OLD AGE). Rip van Winkle, who is the main character of Irving Washington's short story, falls asleep and wakes up 20 years later, unaware of a lot of changes 
in his village and not only. Accordingly, this idiom describes the behavior of the elderly person who is out of touch with the present.

Similarly, the phraseological unit yesterday's man characterizes older people as out-of-date, who have no future and must make way to younger generation. This idiom is very close in its meaning to the definition of old age as [part after prime], when you reach the peak of your professional life and it is finished, you belong to the past and have no prospects for the future.

The idiom that's old hat, stylistically marked as a slang unit, is commonly used in the meaning "old-fashioned; out-of-date". Also, it may be found with the meaning [have existed or been known for a long time, and they have become uninteresting and boring], when the definitional features [uninteresting, boring] can be singled out which are based on the comparison of the older person with some item of clothing, a worn out and hackneyed old hat, which one no longer needs.

The phraseologism old fossil derives from the meaning of the noun fossil which denotes [a remnant, impression, or trace of an organism of past geologic ages that has been preserved in the earth's crust], i.e. very old remains of a plant or animal. Therefore, it is also an insulting term for an old or old-fashioned person. Merriam Websters Online Dictionary gives the following definition - [a person whose views are outmoded], emphasizing on the definitional feature [outmoded].

Another idiom used to refer to older women is the blue-rinse brigade. It is used to provide the negative characterization of OLD AGE, representing those elderly women who gave their white or grey hair a bluish tint produced by certain rinses. It is also found in adjectival form, with the definition [of, for, or composed mostly of elderly women] and is first recorded in the period 1975-80. The entry in YourDictionary marks this unit with stylistic connotation as slang or derogatory term to describe [elderly women with traditional, conservative views]. The definitional features [traditional] or [conservative] add to the conceptualization of prejudiced stereotypes in the structure of the concept OLD AGE. However, Collins English Dictionary gives another definition - [denoting or typifying an elderly, well-groomed, socially active, and comparatively wealthy woman, especially one with conservative views], in which the definitional features [well-groomed], [socially active], and [wealthy] can be highlighted, adding the positive evaluative component to the structure of this idiom's meaning.

3. Older people might be viewed as a burden, when they are said to be boring, annoying and ill-tempered. 
An old wife's (wives') tale - the story that has no foundation in fact;

Old-maidish - fussy, prudish, gossipy, like an old maid;

A dry old stick - a dull boring man with little to say.

In this group of idioms, the elderly are categorized as annoying or fussy people whose behaviour is not commonly approved of by society and who are regarded as a burden, not interesting or important.

The phraseological unit an old wife's(wives') tale, which means [the story that has no foundation in fact], might be motivated by a widely accepted fact that older women have a habbit of giving their advice to the younger people in the form of sayings that are easy to remember. The "wives" does not refer only to married women, but comes from the Old English word wif, which means "woman." Accordingly, older women are viewed as the source of superstitious ideas and beliefs and this unit presents an example of prejudiced stereotyped attitude towards the elderly, women in particular.

The ageist attitude to the elderly women is also encoded in the meaning of another idiom old-maidish - [fussy, prudish, gossipy], i.e. like an old maid, used to designate excessively particular, demanding, or fussy about details people who give careful attention to details, are hard to please and excessively concerned with cleanliness. This and the like culturally loaded stereotypes represent certain patterns of behavior fixed in the structure of phraseological units which serve as a standard of features and are closely connected with the culture code of the people.

The idiom a dry old stick is used to denote [a dull boring man with little to say]. The motivation for its meaning comes from our knowledge about stick, which as a slang unit refers to verbal abuse and criticism. Moreover, in its primary meaning it denotes [a thin piece of wood] which results in the metaphorical mapping from the source domain (a thin piece of wood) to the target domain (an older person, exhausted, ill and skinny, physically incapable).

4. The following group of phraseological units is used to conceptualize older women as unattractive and ugly.

Mutton dressed as lamb - an older woman in clothes suited to a younger age;

An old bag - an older woman with little respect or liking, especially an unpleasant, unattractive old woman.

According to Urban Dictionary, the term "mutton dressed as lamb” was first used in the journal of social gossip that Mrs Frances Calvert compiled in 1811, and is possibly attributed to the then Prince of Wales (later George IV). At a musical evening, the Prince was asked whether he 
did not think some girl pretty. He reputedly answered, "Girl! Girls are not to my taste. I don't like lamb; but mutton dressed like lamb!" This phraseological unit was originally a disparaging description of a woman aiming to deceive men into believing she was younger than she really was. Nowadays, it refers exclusively to a woman who is deluded and thinks herself attractive in clothes, jewellery and make-up usually worn by those much younger.

Another unit, an old bag, might also serve as an example of this disparaging attitude to the elderly in society. It is used to name an older woman with little respect or liking, especially an unpleasant, unattractive old woman. WordNet 3.6 specifies the definition of this unit as [an ugly or ill-tempered woman] with the definitional features [ugly], [ill-tempered] providing the negative axiological interpretation of the features associated with OLD AGE.

5. In the following group, older people are featured as trying to look or act younger than their age.

A sugar daddy - a rich old man who keeps a girl young enough to be his daughter;

A sugar mama - an older woman who spends money on a younger person, usually in exchange for companionship and/or sexual favors;

She's no spring chicken - she's not young as she would like to appear.

The idiom a sugar daddy denotes [an older man who provides lavish and expensive gifts to a young woman in exchange for her companionship and usually, sexual favors]. It is assumed that the word "sugar" has been a slang word for money and luxury since the mid-19th century, and defines the nature of the relationship between the couple. The word "daddy" was slang among prostitutes for an older man since the 16th century, and refers to the age difference between the two. Though the term "sugar daddy" has been used since the beginning of the 19th century, it became a popular idiom only during the 1920s, when Adolph Spreckels, heir to the Spreckel's sugar fortune, married a woman who was 24 years younger than him and called him "Sugar Daddy". However, the first recorded use was in 1923 in the Syracuse Herald in an episode of the story "Fat Anna's Future". ${ }^{20}$ A young woman who was supported by a sugar daddy was known as a sugar baby.

The idiom has become so popular that a new related idiom, sugar mama, has been coined. There is a considerable semantic overlap between a sugar mama and a sugar daddy, although the terms are not

\footnotetext{
${ }^{20}$ Willard J. 'Sugar Daddy’ Has a Sweet History. Feb. 21, 2013. www. reporterherald.com.
} 
synonymous. Accoding to Merriam Webster Dictionary, sugar mama, particularly in its early use, tends to be used in reference to a married woman who is providing financial support, whereas sugar daddy is generally used without connotations of the provider's marital status. These definitions demonstrate that older people do not want to age fast, they still wish to lead an active life style, similar to that of their younger age, especially in their private lives. However, this type of behavior is rarely thought of by society as acceptable or typical of the elderly. The entry in Urban Dictionary might be seen as another proof of this social stereotype, where a sugar mama is defined as [a distinguished species of older females who seek the company of younger males whilst avoiding the entanglements of a relationship, in favor of a lack of restrictions. The sugar mama has overcome society's proscribed behavior for women's sexual behavior. Thus, embraces her true self and lives her life to its fullest. She know what she wants and isn't afraid to hunt for it!] The definitional feature [society's proscribed behavior] specifies the encoded norm of behavior for the elderly established in society, however they are ready to stand against these restrictions - [overcome], to succeed in deeling with this problem and live life to the fullest.

The phraseological unit she's no spring chicken is commonly used to talk about [someone who is no longer young, who can no longer be considered youthful; an old person]. Often used to describe women, it may also be used to characterize men positively with the meaning [when you think someone's appearance or behaviour is surprising for their age]. Although it is usually humorous, it may be considered insulting or rude, usually used in a negative way to describe someone who is no longer young, probably past his young adulthood, and sometimes doesn't realize it and tries to look and act younger than his age. According to Dictionary.com, the origin of the phrase actually comes from its literal meaning. In the early 1700s, farmers found that chickens born in the spring brought better prices than "old" ones that had gone through the winter. When farmers tried to sell the old birds as "new spring born", buyers complained that they were "no spring chicken". The first recorded use of the phrase in its figurative meaning was in 1906.

\section{Moreover, English idioms conceptualize OLD AGE as the end of life.}

For instance, the idiom with one foot in the grave means [on the point of dying]. This phrase has been used in English since the 17th century. It is rather an antiquated expression, but it took an upswing in use, in the UK at least, following the success of the BBC sitcom One 
Foot In The Grave, which was popular throughout the 1990s and starred Richard Wilson as grumpy old man Victor Meldrew (as explained in The Phrase Finder). It is fairly easy to derive the meaning of the phrase as [close to death]. Dictionary.com defines this unit as [to be so frail, sick, or old that death appears imminent], thus highlighting the definitional features [frail], [sick] that compare ageing with desease, the inevitable end of life.

7. Another group of phraseological units is assumed to represent positive associations about OLD AGE as the age of wisdom, rich experience and proficiency which deserve respect.

Not born yesrerday - wise enough not to be easily taken in.

A sly fox, an old fox - experienced, with much guile.

A wise old owl (an old bird) - older people who are too experienced and shrewd.

An old hand - experienced, skillful.

An old war horse - who has a wealth of experience.

Viewed positively, OLD AGE is the state which is not only about decline, it is also the condition that should be praised and valued because the older people are the source of valuable life experience and wisdom. These idioms have positive connotations in their semantic structure emphasizing on such aspects, as wisdom, maturity, respect. They demonstrate that old age should be valued, since it presents the valuable and significant phase of human life, when the older people are responsible for preserving and transferring knowledge in society.

The phraseological unit not born yesrerday is used to encode wisdom as the property of OLD AGE, since the elderly are usually not naive or easily deceived, they have lots of life experience to become "wise to the ways of the world." According to Dictionary.com, this unit gained popularity from the title of Garson Kanin's popular Broadway play, Born Yesterday (in 1950ies).

The idiom a sly fox, an old fox is used with the meaning [experienced, with much guile]. The image of an old fox (sly, cunning, experienced and intelligent) is really common in English lingual culture. Similar meanings can be noted in a number of proverbs, such as An old fox is not easily snared, or Old foxes need no tutors (first recorded in R. Taverner (1539) Proverbs of Adages with New Editions) which are also used to conceptualize wisdom as the property of an older person who, with the years of experience, is unlikely to be easily fooled.

The images of animals, such as bird or owl as the source of metaphorical conceptualization of experience and wisdom that come 
with getting older, are observed in phraseological units a wise old owl and an old bird used to suggest that older people are too experienced and shrewd. The origin of the wise owl dates back to Greek mythology where the owl represents Athena, the goddess of wisdom. In early Indian folklore, owls represent wisdom, helpfulness and they also have the power to predict the future.

Similarly, the unit old bird with the humorous connotation denotes [a wary and astute person]. According to Collins Dictionary, if you describe someone as astute, you think [they show an understanding of behaviour and situations, and are skilful at using this knowledge to their own advantage], while weary means that [you are cautious because you do not know much about them and you believe they may be dangerous or cause problems]. Thus, this unit conceptualizes not only the feature of skillfulness as a property of OLD AGE, but also caution and circumspection as patterns of behavior characteristic of the elderly.

Merriam Webster Dictionary defines an old hand as [a specialist or veteran in a usually designated activity or region]. Collins English Dictionary in its entry states that if someone is old hand, it means that [they are very skilled at it because they have been doing it for a long time]. Thus, the definitional feature [skill/experience] can be considered as the basic property of OLD AGE conceptualized in this unit. In this idiom, practical skills and experience, interpreted metonymically as a hand, in syntagmatic combination with the adjective old, evoke the image of an elderly person, knowledgable and skillful.

An old war horse in its primary meaning is used to denote [a veteran of many battles who likes to reminisce over them]. However, it may also be used when speaking about [a veteran of some activity or profession (not necessarily the military) who has a wealth of experience going through various trials and tribulations or person with long experience in a field]. Thus, the feature [wealth of experience] serves as the motivational basis for this idiom.

8. Furthermore, idioms are used to conceptualize OLD AGE as the period of prolonged activity, energy, vigour and longevity.

There's life in the old dog - still full of energy.

A green old age - the period when mental and physical powers are still strong and vigorous.

To be 100 and not out -100 and still alive.

The third age - the period in life of active retirement.

Silver surfers - elderly people who enjoy using the Internet

Grey power - the mature generation, well-off, active. 
In this group, OLD AGE is conceptualized in line with the the sociological theory of "successful ageing". Older people are seen as energetic, full of vigour and joy, they preserve their interest in life and are ready to adapt to new technologies and continuous self-development.

Stylistically marked as spoken or humorous, the phraseological unit there's life in the old $d o g$ is used to say that [although someone or something is old, they are still able to do something], i.e., despite the appearance, an old person is still full of vigour, enthusiasm, etc. ${ }^{21}$

A green old age is used to denote [the period when mental and physical powers are still strong and vigorous]. Collins Dictionary provides the definition of adjective green as [vigorous], which may serve as a motivational basis for this metaphorical conceptualization of OLD AGE as the period when the elderly are strong, healthy anf full of energy.

The euphemistic expression to be 100 and not out is used to conceptualize longevity as the feature commonly associated with OLD AGE nowadays. Thanks to the developments and innovations in genetics and medicine, older people tend to live not only longer, but also healthier, preserving their cognitive and physical abilities. There appeared a group of centenarians, who are "not out", i.e. still alive.

The idiom silver surfers denotes elderly people who enjoy using the Internet to search for news or information, communicate with their friends. In this figurative conceptualization of older people, "silver" encodes the colour of the hair (grey/greyish as a cosmetic marker of ageing) commonly associated with those who are over 50ies.

The third age refers to the period of active retirement, following middle age. Sociologists promote activity approach to ageing (e.g., Nuland, 2007) that discusses the conceptions of fulfillment, contentment and wellbeing in older age, with further self-realisation and preserved agency. Accordingly, this recently-coined metaphorical name of old age is said to encode the features of [activity], [happiness], [life satisfaction], especially when viewed as an opportunity for travel, further education, etc.

The idiom grey power conceptualizes mature generation, well-off and active. This unit, first recorded in the period 1975-1980, denotes [the organized influence exerted by elderly people as a group, especially for social or political purposes or ends]. The motivation that underlies this idiomatic expression includes visual physical changes in the appearance of the elderly whose hair turns grey when they get older. Moreover, this cohort is known for their authority, wealth and professional experience accumulated by the end of their career. Thus, the motivation in this idiom

\footnotetext{
${ }^{21}$ Farlex Dictionary of Idioms. (2015). https://idioms.thefreedictionary.com.
} 
is rather obvious and comes from the conventional image of the highpowered, influential, respectful older people.

\section{The tendencies in the idiomatic conceptualization of OLD AGE}

Summarizing the results of the analysis conducted in this paper, it seems reasonable to assume that the inner structure of phraseological units schematically represents the way of concept's actualization, i.e. by means of comparison, implications, etc. A number of units prove to be pejoratively marked, emphasizing on the features of decline, loss of energy and mental faculties. In this case, the axiological component is layered over the notional one, thus adding to the negative characterization of OLD AGE, whereas the units with positive connotations provide characterization of this notion as the age of wisdom, longevity, experience etc.

Moreover, there are several phraseological units used to define the period of old age itself: winter of one's life, autumn of one's life, autumn years, twilight years, Indian summer, second childhood. Similar to psychologists, who believe that life seems to operate in seasons ${ }^{22}$, these units demonstrate a common tendency to draw analogies comparing the stages of life with the seasons of the year, e.g., winter of one's life, autumn of one's life, autumn years. When you are young, it is the beginning of your life, compared to spring, with new hopes and prospects for development. Summer comes as a period of pleasure and delight for young adults, while autumn brings maturity. However, winter is viewed as the end of the life cycle, thus the aged might experience the winter of their lives.

As it is emphasized in recent cognitive semantic studies, the analyzability and compositionality of idioms point to the idea that the meaning of the constituents of the idioms might be related to the concepts to which the idioms actually refer. ${ }^{23}$ Accordingly, the metaphor winter of one's life compares OLD AGE to this seasons, with its cold hostile weather conditions that cause the dying of nature. The cold, bitter harshness of this season is taken as the basis of motivation, mapping the information from the source domain - winter - to the target domain OLD AGE - the conceptual features being [cold period], [the end].

The idiom autumn years is defined as [the later years of someone's life, especially after they have stopped working]. Collins Dictionary broadens the categorization of this period as [a period of late maturity,

${ }^{22}$ Tongeren van Daryl R. The Seasons of Life: or How to Survive Life's Winter Moments. How to thrive during all of life's seasons. Feb. 24, 2015. www.psychologytoday.com.

${ }^{23}$ Benczes R. The semantics of idioms: a cognitive linguistic approach. // The Even Yearbook, 5, 2002. P. 20. 
esp. one followed by a decline]. Metaphor autumn represents OLD AGE as years after the period of spring with "new beginnings, a fresh start, a brand new job, or a creative opportunity" and summer when "relationships are thriving, work seems effortless, and the pleasant days are long" 24 . Autumn brings sadness and nostalgia of the past youth and the lost days. As proved by Lakoff, conventional images are important to explain the meanings of idioms in terms of their motivation ${ }^{25}$. Thus, the mental image of autumn shared by the English-speaking community helps to conceptualize OLD AGE as declining years.

The unit twilight (years) is also defined as [the last years of someone's life]. The analysis of different lexicographical sources leads to the conclusion that the noun twilight in English is used to represent [the time just before night when the daylight has almost gone but when it is not completely dark]. Also, it is commonly used to denote [any late period, when the end of something is near] or [a period or state of obscurity, ambiguity, or gradual decline]. This idiom presents the metaphorical conceptualization of OLD AGE which leads to DARKNESS, i.e. death, because the daylight when you are young - is almost gone. The definitional features [decline], [late period], [the end] accentuate the image of old age with negative connotations as a gloomy, depressing and frightening life period.

Another metaphorical conceptualization of OLD AGE is based on the positive evaluational semantics of the phrase an Indian Summer which, in its direct meaning, is used to express [a period of unseasonably warm weather in early fall]. Similarly, old age is defined as [a period of great happiness that comes late in a person's life], which points to the definitional feature [happiness] in the structure of the concept's nominative field. Also, the sememe [a tranquil or productive period in someone's later years] outlines the definitional features [tranquil period], [productive period] which belong to the temporal segment and characterize OLD AGE as a period, when you still enjoy success in your career and private life.

Another phraseological unit, second childhood, encodes the meaning of cognitive decline of the elderly, their regression leading to childish behaviour. Its dictionary definitions [the simple mindedness of old age which resembles the mind of the child; illness], [mental weakness caused by old age] prove to display a special figurative meaning that compares the state of being old with that of childhood. At the same time, quite

\footnotetext{
${ }^{24}$ Tongeren van Daryl R. The Seasons of Life: or How to Survive Life's Winter Moments. How to thrive during all of life's seasons. Feb. 24, 2015. www.psychologytoday.com.

${ }^{25}$ Lakoff G. Women, Fire, and Dangerous Things: What Categories Reveal about the Mind. Chicago \& London: The University of Chicago Press, 1987. P. 448.
} 
noticeable in the structure of the dictionary entries are definitional features [illness], [mental weakness] which add to the negative characterization of OLD AGE.

The second tendency observed within the idiomatic segment of the concept's nominative field is the use of a number of comparative constructions, such as as old as the hills, as old as Methuselah, as old as Adam. Standard images in these fixed comparative constructions correlate one object or person (the source domains) with another (the target domain - state of being old).

Thus, for example, the origin of the idiom as old as the hills is Biblical. It is derived from Job, 15:7 and in its present meaning it refers to geological time (when mountains were created).

Almost synonymic phraseological unit as old as Adam alludes to the first human created by God, according to the Bible, and was first recorded only in 1867.

The phraseologism as old as Methuselah, that can be traced back to at least the 14th century, with the meaning "very old" compares the age of the elderly person to that of Methuselah who was a Hebrew patriarch and was supposed to have lived for 969 years.

Thus, standard images (Methuselah, Adam, the hills) in these fixed comparative units serve as key points to understanding the knowledge encoded in the structure of the concept. These three idioms are used to express existential characteristics of OLD AGE with the meaning "very old".

Idiomatic conceptualization of OLD AGE is achieved not only in comparative constructions, but also allusions: e.g., out of the Ark, before the Flood, etc.

Thus, the phraseological unit out of the Ark alludes to a well-known story in the Bible about The Ark, a large boat which Noah built to save his family and two of every type of animal from the flood. It is used to denote the person who is very old or old-fashioned.

The phrase before the Flood is used to verbalize the existential property with the meaning that something exists very long. It is close to the meaning of adiective antediluvian, which derives from Latin ante "before" + diluvium "a flood". Hence, humorously or disparagingly with the meaning "very antiquated" it has been used since 1726, as a noun meaning "person who lived before the Flood" from 1680s.

As the material analysed shows, the images of animals, such as old bird or old owl, old fox, old horse as the source of metaphorical conceptualization of experience and wisdom that come with getting older, 
are observed in praseological units a wise old owl and an old bird, or a sly fox, an old fox. These units are assumed to conceptualize older people who are experienced and shrewd, not easily fooled.

However, in the phraseological unit no spring chicken the motivational basis is different and derives from the source domain SPRING representing young age, immaturity, while the use of the negative pronoun no results in the conceptualization of the opposite feature - no longer young.

Finally, it should be mentioned that English idioms tend to conceptualize a number of prejudiced ageist stereotypes towards the elderly, women in particular: e.g., Old-maidish, old wives' tales, an old bag, blue-rinse brigade, mutton dressed as lamb, etc.

\section{CONCLUSIONS}

The results of the preliminary analysis of phraseological expressions lead to the logical conclusion as to the main conceptual features of OLD AGE, which represent national and/or universal stereotypes:

- Old age is the period of human life;

- Old age is old-fashioned and annoying;

- Old age is inevitable, it is the end of the life cycle, bringing death;

- Old age is the decline of physical strength, the loss of health and beauty;

- Old age is life experience and wisdom;

- Old age is longevity and preserved activity.

Moreover, idiomatic expressions are commonly motivated by metaphors, metonymies or conventional knowledge shared by the linguocultural community. The interactions between different structures of knowledge cause a number of associations. Thus, life stages are metaphorically compared with the seasons, where OLD AGE is the end of the year, autumn or winter. Grey or silver are commonly associated with the late adulthood and are found in a number of phraseological uints. Life is viewed as a journey with its beginning - early childhood and the logical inevitable end - old age and death. Idiomatic conceptualization of OLD AGE is achieved in comparative constructions and allusions.

Moreover, some of the examples might indicate that phraseological units designate people pointing to their main characterizing properties: no spring chicken, grey hairs, or describe them by comparing to the phenomena of nature: as old as the hills, old bird, old fossil.

Furthermore, the verbalization of the concept OLD AGE at the phraseological level has proved to be influenced by euphemisation and 
widespread use of zoonims as components of phraseological units. Nominative units used to encode certain characteristics of elderly women tend to be negative and represent ageist stereotypes accentuating on ill temperament, unpleasant, sometimes conservative appearance, ridiculous desire to look younger and hide their age.

The prospects of further research might be in the study of conceptual metaphors of OLD AGE in different types of discourse.

\section{SUMMARY}

This research aims at revealing what old age is and how ageing is conceptualized by means of phraseological units in relation to the cultural context and its values. Idioms are important constituents of language world view and define its national and cultural properties. The nominative field of the concept OLD AGE, represented by English idioms, is sudivided into several thematic domains and is focused on moral-ethical and psycho-physical aspects, expressing the attitude to and associations about the phenomenon of old age in the English speaking society. The results of the analysis prove that phraseological units are commonly motivated by metaphors, metonymies or conventional knowledge shared by the linguocultural community. As to the main conceptual features of OLD AGE, they represent national and universal stereotypes. Further research may be conducted into the study of conceptual metaphors of OLD AGE in different types of discourse.

\section{REFERENCES}

1. Benczes R. The semantics of idioms: a cognitive linguistic approach. // The Even Yearbook, 5, 2002. P. 17-30.

2. Gibbs R. W. The Poetics of Mind. Cambridge: Cambridge University Press, 1994.

3. Gibbs R. W., de Macedo A. Cristina P. S. Metaphor and Embodied Cognition (Metáfora e cognição corpórea). D.E.L.T.A., 26:especial, 2010 P. 679-700.

4. Kövecses Z., Szabó P. Idioms: A View from Cognitive Semantics. Applied Linguistics, 17, 1996. P. 326-355.

5. Lakoff G., Johnson M. Metaphors we Live by. Chicago: University of Chicago Press, 1980.

6. Lakoff G. Women, Fire, and Dangerous Things: What Categories Reveal about the Mind. Chicago \& London: The University of Chicago Press, 1987.

7. Nuland S. The art of aging. New York: Random House, 2007. 
8. Tongeren van Daryl R. The Seasons of Life: or How to Survive Life's Winter Moments. How to thrive during all of life's seasons. Feb. 24, 2015. www.psychologytoday.com

9. Wierzbicka A. Understanding Cultures through Their Key Words. N.Y.; Oxford: OUP, 1997. 317 p.

10. Willard J. 'Sugar Daddy' Has a Sweet History. Feb. 21, 2013. www. reporterherald.com.

11. Алефиренко Н.Ф. Фразеология в свете современных лингвистических парадигм. М.: ООО Изд-во «Элипс», 2008. 271 с.

12. Антология концептов. Ред. В.И. Карасик, И.А. Стернин. М. : Гнозис, 2007. 512 с.

13. Бешлей О. В. Концепт youth в англомовній картині світу (на матеріалі фразеологічних одиниць). // Науковий вісник ДДПУ імені І.Франка. Серія «Філологічні науки». Мовознавство. Том 1. № 5. 2016. С. 27-31.

14. Болдырев Н.Н. Концепт и значение слова. // Методологические проблемы когнитивной лингвистики: научное издание. Воронеж, 2001. С. 25-36.

15. Иванова Е.В. Мир в английских и русских пословицах. СПб.: Изд-во С.-Петерб. ун-та, 2006. 278 с.

16. Калько В. Концепти МОЛОДІСТЬ і СТАРІСТЬ в українській мові (на матеріалі паремій). // Лінгвістичні студії : Збірник наукових праць. Донецьк, 2012. Вип. 24. С. 110-114.

17. Карасик В.И. Языковой круг: личность, концепты, дискурс. Волгоград: Перемена, 2002. 477 с.

18. Маслова В.А. Лингвокультурология: учеб. пособие для студ. высш. учеб. зав. М. : Издательский центр «Академия», 2001. 208 с.

19. Никитин М.В. Развернутые тезисы о концептах. // Вопросы когнитивной лингвистики. 2004. № 1. С. 53-64.

20. Селіванова О. Нариси 3 української фразеології (психокогнітивний та етнокультурний аспекти): монографія. К. Черкаси: Брама, 2004. 276 с.

21. Селіванова О. Сучасна лінгвістика: термінологічна енциклопедія. Полтава: Довкілля-К, 2006. 716 с.

22. Телия В.Н. Метафора как модель смыслопроизводства и ее экспрессивно-оценочная функция. // Метафора в языке и тексте. М., 1988. С. 173-203.

23. Телия В.Н. Русская фразеология: Семантический, прагматический и лингвокультурный аспекты. М.:«Языки русской культуры», 1996. 284 с. 
24. Телия В.Н. Фактор культуры и воспроизводимость фразеологизмов - знаков - микротекстов. // Сокровенные смыслы. Слово. Текст. Культура. М., 2004. С. 674-684.

\section{SOURCE MATERIAL}

Cambridge Advanced Learner's Dictionary. www. dictionary. cambridge.org.

Collins English Dictionary. www. collinsdictionary.com.

Dictionary of Idioms and Their Origins. Ed. Flavell L., Flavell R. L.: Kyle Books, 2006. 343 p.

Dictionary.com. https://www.dictionary.com.

Longman Dictionary of Contemporary English. https://www.ldoceonline.com.

Merriam .Websters Online Dictionary. https://www.merriamwebster.com

The Free Dictionary. https://www.thefreedictionary.com.

The Penguin Dictionary of English Idioms. Ed. Gulland D., HindsHowell D. L.: Penguin books, 2002. 378 p.

The Phrase Finder. https://www.phrases.org.uk.

Urban Dictionary. https://www.urbandictionary.com.

Word Net Dictionary Online. https://www. wordnet.princeton.edu.

YourDictionary. www.yourdictionary.com.

Information about the author: Holyk S. V., Candidate of Philological Sciences, Associate Professor, Head at the English Philology Department, State University "Uzhhorod National University” 14, Universytetska str., Uzhhorod, 88000, Ukraine 